\title{
Microbial erosion assessment on waterlogged archaeological woods (WAWs) from a Chinese ancient shipwreck, Nanhai No. 1
}

\author{
Mengge Gao ${ }^{1,2 \dagger}$, Qinfen Zhang ${ }^{1 \dagger}$, Xinxin Feng ${ }^{1,3}$, Dong Chen ${ }^{1}$, Jian Sun ${ }^{4}$, Yong Cui ${ }^{5}$ and Runlin Xu ${ }^{1 *}$ (i)
}

\begin{abstract}
This article aims at identifying the timber species of Nanhai No. 1, an ancient shipwreck (Song Dynasty, 800 years ago) sunk in the South China Sea, finding out the types of bacteria that corrode the wood components of the shipwreck and analyzing the erosion level. The changes of the internal structure of wood under different erosion degrees are described as well. With light microscope and electron microscope technology, the microscopic and submicroscopic structures of 20 wooden components from the shipwreck were investigated. The shipwreck was built of 6 timber species, including Pinus massoniana, Fokienia hodginsii, Terminalia hainanensis, Mischocarpus oppositifolius, Alnus trabeculosa and Mussaendopsis beccariana. Based on analyzing the traces left after bacterial erosion, it was determined that the erosive microbes in the sunken ship were mainly erosion bacteria and tunneling bacteria. According to the criteria from relevant literature, the analysis on the bacterial erosion degree of each wood sample shows that most of the wood components present weak to moderate erosion, except a few samples which are totally degraded. Comparison with the bacterial erosion on the wooden components of different ancient shipwrecks, sunk in different years in the southeast China, it is noticed that due to the different seabed environments (sunk conditions), the wood structure of the Nanhai No. 1 sunken ship is the best preserved although its sunken time is longer than the others. The silt-covered anaerobic environment could be one of the protective measures which preserves the ancient sunken ships.
\end{abstract}

Keywords: Waterlogged archaeological wood (WAW), Timber species, Microbial erosion, Ancient shipwreck, Nanhai No. 1

\section{Introduction}

Wooden relics are one of the important artefacts reflecting the ancient civilization of mankind. Similar to other cultural items, wooden relics are also valuable materials for studying the history, art, science, technology, and economic development of ancient times. Being precious and fragile, the wooden relics are also a kind of non renewable and individualized cultural record [1]. The main components of the ancient sunken ship are made of various kinds of wood. The basic structural unit of the wooden

\footnotetext{
*Correspondence: xurunlin_1960@yahoo.com

${ }^{+}$Mengge Gao and Qinfen Zhang contributed equally to this work

${ }^{1}$ School of Life Sciences, Sun Yat-sen University, Guangzhou 510275,

China

Full list of author information is available at the end of the article
}

relics is the higher plant cells, with the complex cell wall structure as one of the characteristics of the plant cells.

Since the middle of the twentieth century, biology theory has been used to assess the preservation of all kinds of cultural relics by European researchers, and the protection of cultural relics has been improved based on assessment [2-4]. Many studies have been reported and published on the analysis and protection of underwater wooden heritage including the erosion characteristics of harmful microorganisms, and the erosion rate of different components of cell walls worldwide [5, 6].

The previous studies show that the deterioration of underwater archaeological wood bacteria are mainly three types, erosion bacteria (EB), tunnelling bacteria (TB) and cavitation bacteria (CB); with $\mathrm{EB}$ and TB the common ones [7]. In terms of the erosion effects, EB 
form erosion grooves on the smooth inner surface of plant cell walls; TB decompose the polysaccharides and lignin of plant cell walls, resulting in softening and darker color of wood artifacts; while CB make cavitations to cell walls [8].

The assessment of bacterial erosion degree on wooden artifacts is of great importance to the cultural relics excavation plan, and the follow-up protection measures. Meanwhile, it has great practical significance on evaluating whether the protection measures in the collection status are scientific and reasonable [9].

With the improvement of underwater archaeology in China, many ancient sunken ships were discovered and excavated in succession, for example, Song Dynastic wooden ship from Quangzhou in 1976 [10]; Xiaobiaojiao No. 1 shipwreck from Zhejiang in 2012 [11]; Huaguangjiao No. 1 shipwreck from Sansha in 1996 [12]; and Nan'ao No. 1 shipwreck from Shantou in 2010 [13]. For assessing underwater wooden artifacts (including wooden ship hulls and cargoes), the physical and chemical analysis is supported with evaluation methods that have been used in many cases [14-19]. However, the reports on the wooden structure of ancient shipwrecks in China are rare.
The purpose of this study is, using observation on the micro and submicroscopic structures of wooden samples from Nanhai No. 1 shipwreck which belong to the South Song Dynasty (1127-1279 A.D.), to understand the basic situation of the shipwrecked hull and to provide scientific basis for subsequent protection.

\section{Materials and methods}

\section{A brief introduction of Nanhai No. 1 shipwreck}

The Nanhai No. 1 wreck was discovered in 1987 and initially identified as a pointed ship $30.4 \mathrm{~m}$ in length, $9.8 \mathrm{~m}$ wide, and a $4 \mathrm{~m}$ hull height. The displacement was estimated about $600 \mathrm{t}$, and approximately $800 \mathrm{t}$. After a preliminary exploration, it was confirmed that the wreck was an ancient sunken ship and built more than 800 years ago-in the early years of the Song Dynasty. The goods carried in the ship implied that the ship sunk during the transporting of porcelain abroad on the maritime Silk Road. The wreck site is located at the sea area of Yangjiang, Guangdong, China (Fig. 1a) [20]. The sunken ship was considered to be the oldest ship with the largest hull, and the most completely preserved until now, among all of the sunken oceangoing trade merchant ships in the world. The discovery of the Nanhai No. 1 wreck provides

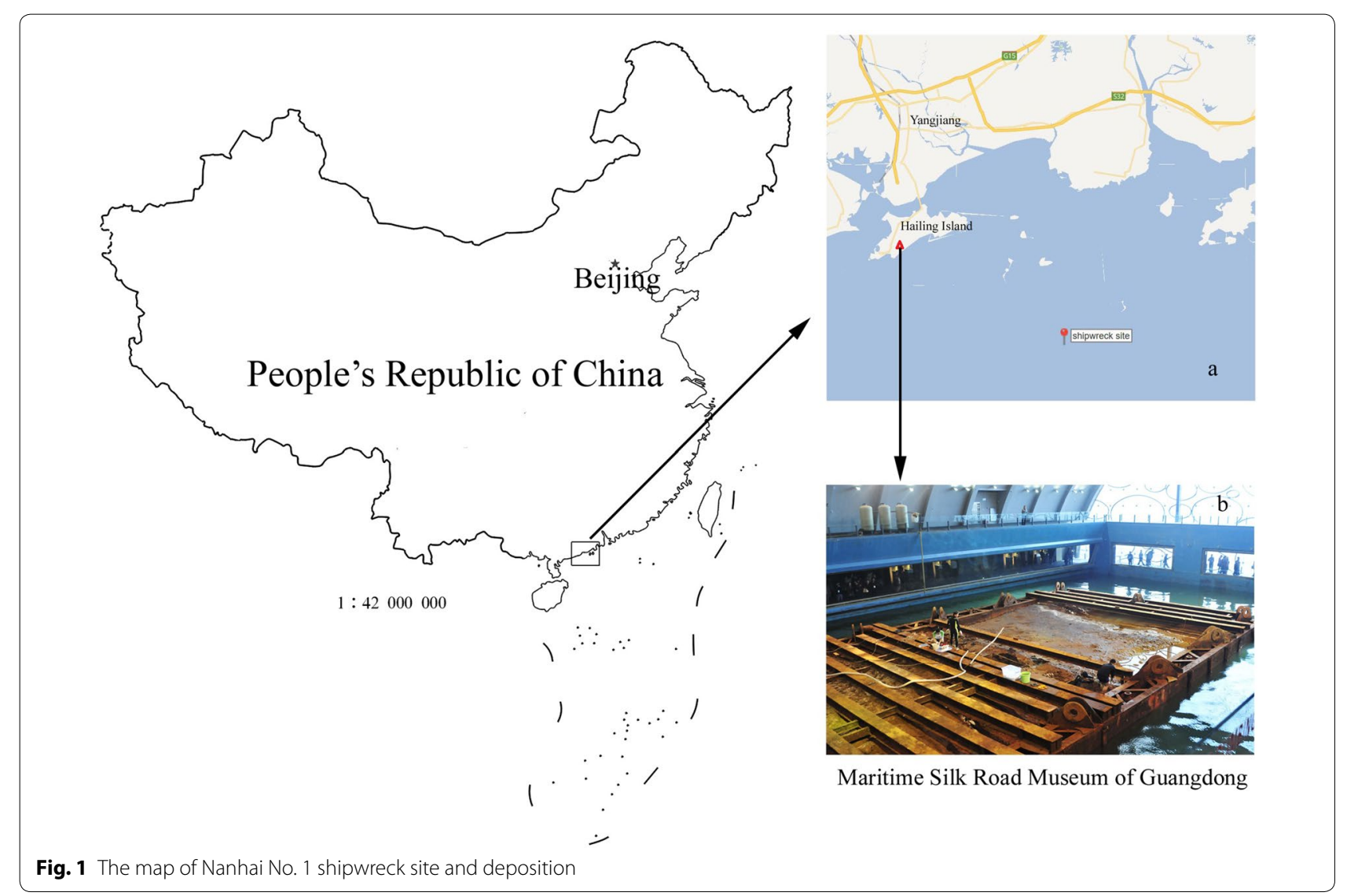


a typical sample for the studies on the ancient Chinese shipbuilding technology, navigation technology and longterm preservation of wooden relics. Meanwhile, it provides extremely rare material information, which cannot be retrieved from the field archaeology or historical literatures, for restoring the histories of the Maritime Silk Road.

After a long period of preparation, Nanhai No. 1 shipwreck was salvaged from the sunken site on 22nd of December in 2007, and preserved in the Maritime Silk Road Museum of Guangdong in Yangjiang [21] (Fig. 1b). The ship has been excavated comprehensively on site by the archaeological department researchers since 28th of November in 2013 (Fig. 2) [22].

\section{Sample collection}

With the cooperation of the archaeologists, from April to December 2014, wood samples for this study were collected from different archaeological relics (so called components), that were excavated from the various quadrats soaked in the seawater pools at the Maritime Silk Road Museum of Guangdong. A sample with a size of $2 \mathrm{~cm} \times 2 \mathrm{~cm} \times 3 \mathrm{~cm}$ was collected at $1 \mathrm{~cm}$ below the surface of each component. A total 20 samples of cultural wooden relics were collected (Table 1). The obtained samples were kept in a refrigerator at $-4{ }^{\circ} \mathrm{C}$.

\section{Wood sample treatments \\ Samples for light microscope observations}

The softening, sectioning, staining and mounting of wood samples were carried out as previously described by Cheng et al. [23] and $\mathrm{He}$ [24].

\section{Samples for transmission electron microscope (TEM) observations}

About $1 \mathrm{~mm}$ thick slices were cut from the different surfaces of the wood sample, and then each slice was cut into $1 \mathrm{~mm}^{3}$ small blocks using a single side blade. The small wood blocks were soaked in a mixture of $3 \%$ glutaraldehyde and 5\% paraformaldehyde, and vacuumized to exclude the air in the blocks, facilitating the infiltration of fixed liquid into the inner part of the wood samples [7]. The fixed sample blocks were washed several times by $0.1 \%$ phosphoric acid buffer (PBS), followed by a secondary fixation with $1 \%$ osmium tetroxide. After being washed several times by $0.1 \%$ PBS once again, the wood
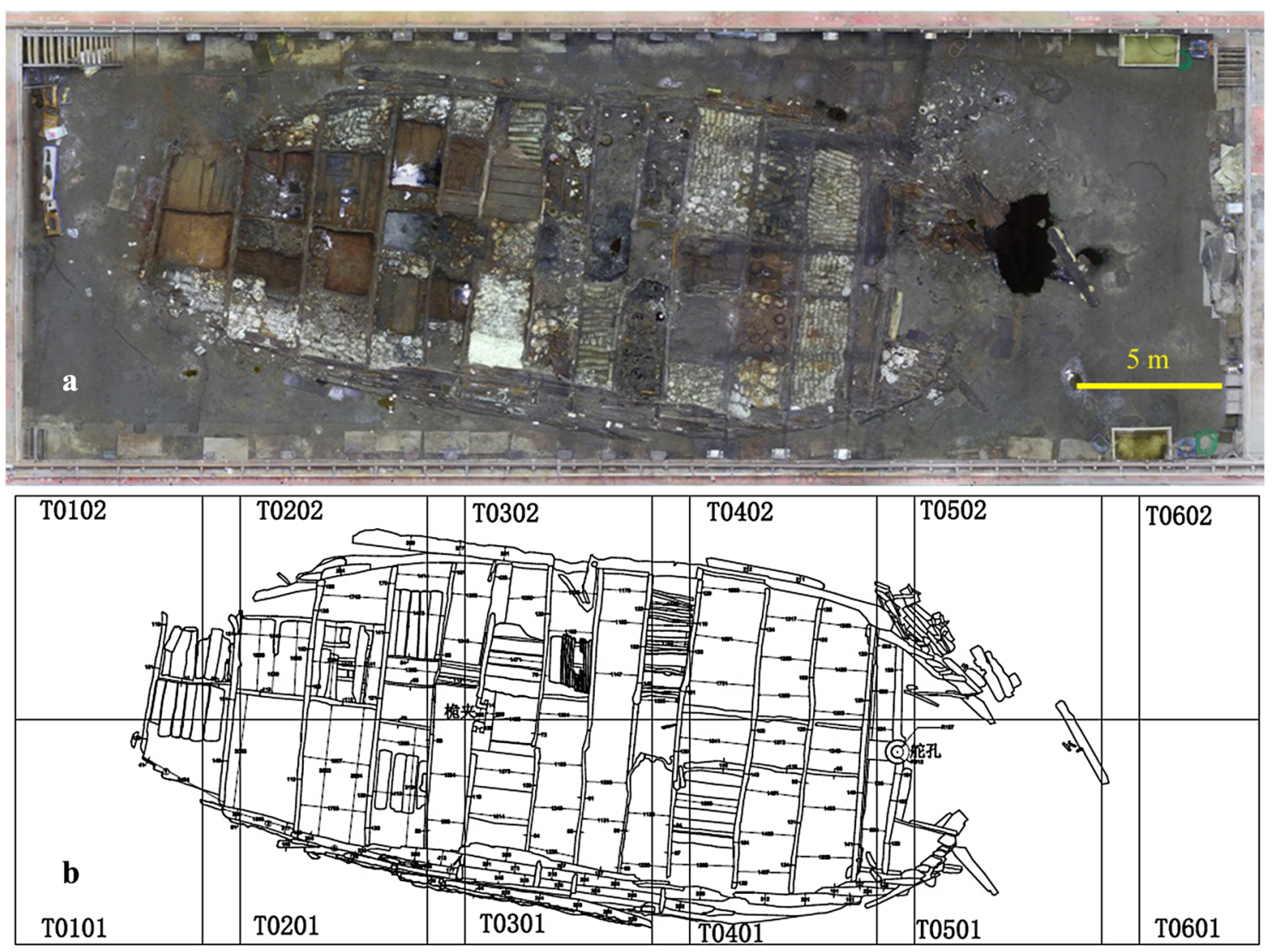

Fig. 2 Overlook of archaeological excavations on sunken ship (a) and a schematic diagram (b) of shipwreck structure (shown the quadrats) 
Table 1 The information of wood samples from Nanhai No. 1 shipwreck

\begin{tabular}{|c|c|c|}
\hline Sample no. & Excavate quadrat-wood number & Date of excavation \\
\hline 1 & 2014NHI-T0301(2)-W9 & 2014 Oct 30 \\
\hline 2 & 2014NHI-T0601(4)-W19 & 2014 Nov 27 \\
\hline 3 & 2014NHI-T0502(4)-W9 & 2014 Nov 8 \\
\hline 4 & 2014NHI-T0102(2)-W7 & 2014 Apr 9 \\
\hline 5 & 2014NHI-T0301(3)-W13 & 2014 Nov 9 \\
\hline 6 & 2014NHI-T0502(4)-W7 & 2014 Nov 7 \\
\hline 7 & 2014NHI-T0502(4)-W24 & 2014 Nov 26 \\
\hline 8 & 2014NHI-T0502(4)-W17 & $2014 \operatorname{Dec} 3$ \\
\hline 9 & 2014NHI-T0102(2)-W5 & 2014 Apr 4 \\
\hline 10 & 2014NHI-T0201-wide portside & 2014 Nov 12 \\
\hline 11 & 2014NHI-T0301 (3)-W12 & $2014 \operatorname{Dec} 3$ \\
\hline 12 & 2014NHI-T0301(3)-W4 & 2014 Nov 11 \\
\hline 13 & 2014NHI-T0602(2)-W1 & 2014 Apr 17 \\
\hline 14 & 2014NHI-T0102(2)-W12 & 2014 May 13 \\
\hline 15 & 2014NHI-T0502(2)-W2 & 2014 Apr 8 \\
\hline 16 & 2014NHI-T0501 (3)-W3 & 2014 Apr 18 \\
\hline 17 & 2014NHI-T0302(2)-W1 & 2014 Apr 24 \\
\hline 18 & 2014NHI-T0301 (3)-W6 & 2014 Nov 13 \\
\hline 19 & 2014NHI-T0301(2)-W13 & 2014 Oct 31 \\
\hline 20 & 2014NHI-T0201(2)-W1 & 2014 Nov 13 \\
\hline
\end{tabular}

samples were made into embedding blocks by ethanol gradient dehydration, osmosis and epoxy resin embedding [25]. The embedded blocks were sliced up into ultrathin sections of $90-100 \mathrm{~nm}$ thickness with Leica EM UC7 ultra-microtome (Leica, Germany). Ultrathin slices were dyed with uranium acetate and lead citrate, after copper net fishing [26].

Samples for scanning electron microscope (SEM) observation The wood blocks, with sizes of $3 \times 4 \times 5 \mathrm{~mm}^{3}$ were fixed as described by Daniel and Nilsson [7]. Fixed samples were washed with $0.1 \%$ PBS several times, gradient dehydrated with ethanol, displaced with butanol [27], and $4 \mathrm{~h}$ after being freeze-dried with JFD-320 freeze-drier (Japanese Electronics Company, Japan), the samples were mounted and sprayed gold.

\section{Sample observations}

A Nikon E-800 light microscope (Japan) was used to observe the longitudinal, transverse and tangential sections of wood samples, under magnification of $\times 100$ and $\times 400$, respectively. The characteristic of each wood sample was measured with software (Leica Microsystems).

The electron microscopy observations were performed with $100 \mathrm{kV}$ JEM-100CX II TEM (Japan) and $15 \mathrm{kV}$ JSM6330F SEM (Japan).

\section{Identification of the wood species}

The wood species were identified referring to the descriptions from the literatures, including Cheng et al. [23], Jiang et al. [28], Editorial Committee of China Flora [29], Richter et al. [30], and Inside Wood Database [31].

\section{Evaluation of bacterial degradation of wood samples}

The classification of bacterial erosions degrees on the woods suggested by Klaassen [32], was used as a criterion for evaluating the damage of wood in this work.

According to Klaassen, bacterial erosions of most shipbuilding hardwoods under seawater conditions can be classified into the following grades:

Absent erosion All cell walls smooth, clear intensive birefringence under polarised light.

Weak erosion Ray cell walls and parts of isolated late wood (LW) tracheids cell walls degraded in longitudinal sections "V" shaped notches of eroded cell-wall material, along with smaller "V" shaped notches in the $S_{1}$ layer and larger notches reaching with the pointed side of the "V" in the $S_{1}$ layer; notches concentrated near Racheid-ray connections; in some early wood (EW) tracheids cell wall with small eroded grooves.

Moderate erosion Isolated degraded cells in a matrix of sound cells with a higher intensity round the rays, larger notches in more (adjacent) LW tracheids; notches further away from the tracheid-ray connection, coalescent; within a tracheid demarcation between sound and degraded cell-wall parts sharp, at an angle of about $45^{\circ}$ to cell axis; in more EW tracheids eroded areas in a grooved-like.

Severe erosion Isolated sound cells in a matrix of degraded cells, diffuse almost all tracheid cell walls fully eroded and filled with amorphous residue material; EW tracheid cell wall fully eroded in grooved-like pattern following more or less the micro-fibrilaire angle; in some tracheids small areas with intact cell wall, sharply separated from completely degraded cell-wall areas with the separating line orientated at angle of $45^{\circ}$ to cell axis.

Total disintegration Although different cell types still are recognized, all cell walls completely eroded except for the compound middle lamella and some parts of the $\mathrm{S}_{3}$; all former cell layers substituted by an amorphous residue material; no birefringence and no clear pattern of degradation visible.

\section{Results}

Wood species and erosion degrees of the shipwreck

A total of 6 plant species, belonging to tropical and subtropical plants, were identified from 20 wood samples. There were 2 gymnosperm species and 4 angiosperm species, including Pinus massoniana Lamb., Fokienia hodginsii (Dunn) Henry et Thomas, Terminalia 
hainanensis Exell, Ischocarpus oppositifolius Merr., Alnus trabeculosa Hand.-Mazz. and Mussaendopsis beccariana Baillon (Table 2). The degrees of bacterial erosion for all samples are listed in Table 2.

\section{Changes of wood internal structure at different levels of erosion}

According to the erosion degrees from absent to severe, the microscopic and submicroscopic structures of the timber samples of the Nanhai No. 1 sunken ship are shown in Figs. 3, 4, 5, 6 and 7 in order.

Figure 3 shows the results of samples without damage trace under SEM observation. At the macro level, these samples had great hardness, and were dark or normal yellow-white in external color. No clear erosion traces by bacteria were found. The cell structure was fine and close, and exhibits good connections between different cell layers with complete cells in Sample 8 (Fig. 3a). Bordered pit, pit membrane and pit plug were easily identified (Fig. 3b). Similar results show in Sample 20 (Fig. 3c), with intact pit membrane and pit plug (Fig. 3d). In samples 15 and 17, cross field pits (Fig. 3e) and vessel pits (Fig. 3f) can be observed as well. The existence of these structures also indicated that the structures of these wood cells were complete.

From Figs. 4, 5, 6 and 7, the cell erosions in different samples display from weak, moderate to severe, followed by total disintegration. In weak erosion, the cells in the samples were slightly deformed without any change in their internal structure. There was slight discoloration and breakup between the cell cavity and secondary cell wall (Fig. 4a). In some samples, oval-shaped cells were found, with no obvious boundary between the cell cavity and the secondary cell wall; hollow corners of the cells; and only the part $S_{2}$ layer, close to the cell cavity slightly discoloured (Fig. 4b). Under optical microscopy, the tangential section also showed that the ray cells were closely connected to the surrounding cells, and only a small amount of erosion was present (Fig. 4c), as well as a slight erosion in ray cells from longitudinal section (Fig. 4d).

In moderate erosion samples, the $\mathrm{S}_{3}$ layer of the secondary wall appeared to be completely or partially degraded in the cells (Fig. 5a). In the tracheids of coniferous wood, for example, Pinus massoniana, the bacterial colonies formed (Fig. 5b). It could be found that both ray cells and tracheids showed the erosions (Fig. 5c), but the duct wall of broad-leaved trees, for instance, Alnus trabeculosa, became soft only (Fig. 5d).

In the eroded sample woods, many bacteria were active in the cell cavity, with erosion residue (Fig. 6a, b). However, in some samples, the erosion residue in the cell cavity was reduced significantly. It can be speculated that these bacteria were not the primitive erosion bacteria, but could be the secondary bacterial degraders

Table 2 The wood species from Nanhai No. 1 shipwreck and the corrosion degrees

\begin{tabular}{|c|c|c|c|}
\hline Sample no. & Excavate quadrat-wood number & Wood species & Corrosion degree ${ }^{a}$ \\
\hline 1 & 2014NHI-T0301 (2)-W9 & Pinus massoniana & Absent \\
\hline 2 & 2014NHI-T0601(4)-W19 & Pinus massoniana & Weak \\
\hline 3 & 2014NHI-T0502(4)-W9 & Pinus massoniana & Weak \\
\hline 4 & 2014NHI-T0102(3)-W7 & Alnus trabeculosa & Weak \\
\hline 5 & 2014NHI-T0301 (3)-W13 & Pinus massoniana & Weak \\
\hline 6 & 2014NHI-T0502(4)-W7 & Mussaendopsis beccariana & Moderate \\
\hline 7 & 2014NHI-T0502(4)-W24 & Pinus massoniana & Weak \\
\hline 8 & 2014NHI-T0502(4)-W17 & Fokienia hodginsii & Absent \\
\hline 9 & 2014NHI-T0102(2)-W5 & Pinus massoniana & Moderate \\
\hline 10 & 2014NHI-T0201-wide portside & Alnus trabeculosa & Severe \\
\hline 11 & 2014NHI-T0301(3)-W12 & Terminalia hainanensis & Total \\
\hline 12 & 2014NHI-T0301 (3)-W4 & Terminalia hainanensis & Severe \\
\hline 13 & 2014NHI-T0602(2)-W1 & Alnus trabeculosa & Severe \\
\hline 14 & 2014NHI-T0102(2)-W12 & Pinus massoniana & Absent \\
\hline 15 & 2014NHI-T0502(2)-W2 & Mischocarpus oppositifolius & Absent \\
\hline 16 & 2014NHI-T0501 (3)-W3 & Pinus massoniana & Moderate \\
\hline 17 & 2014NHI-T0302(2)-W1 & Terminalia hainanensis & Severe \\
\hline 18 & 2014NHI-T0301 (3)-W6 & Terminalia hainanensis & Total \\
\hline 19 & 2014NHI-T0301(2)-W13 & Mussaendopsis beccariana & Total \\
\hline 20 & 2014NHI-T0201(2)-W1 & Fokienia hodginsii & Absent \\
\hline
\end{tabular}

according to Klaassen [32] 

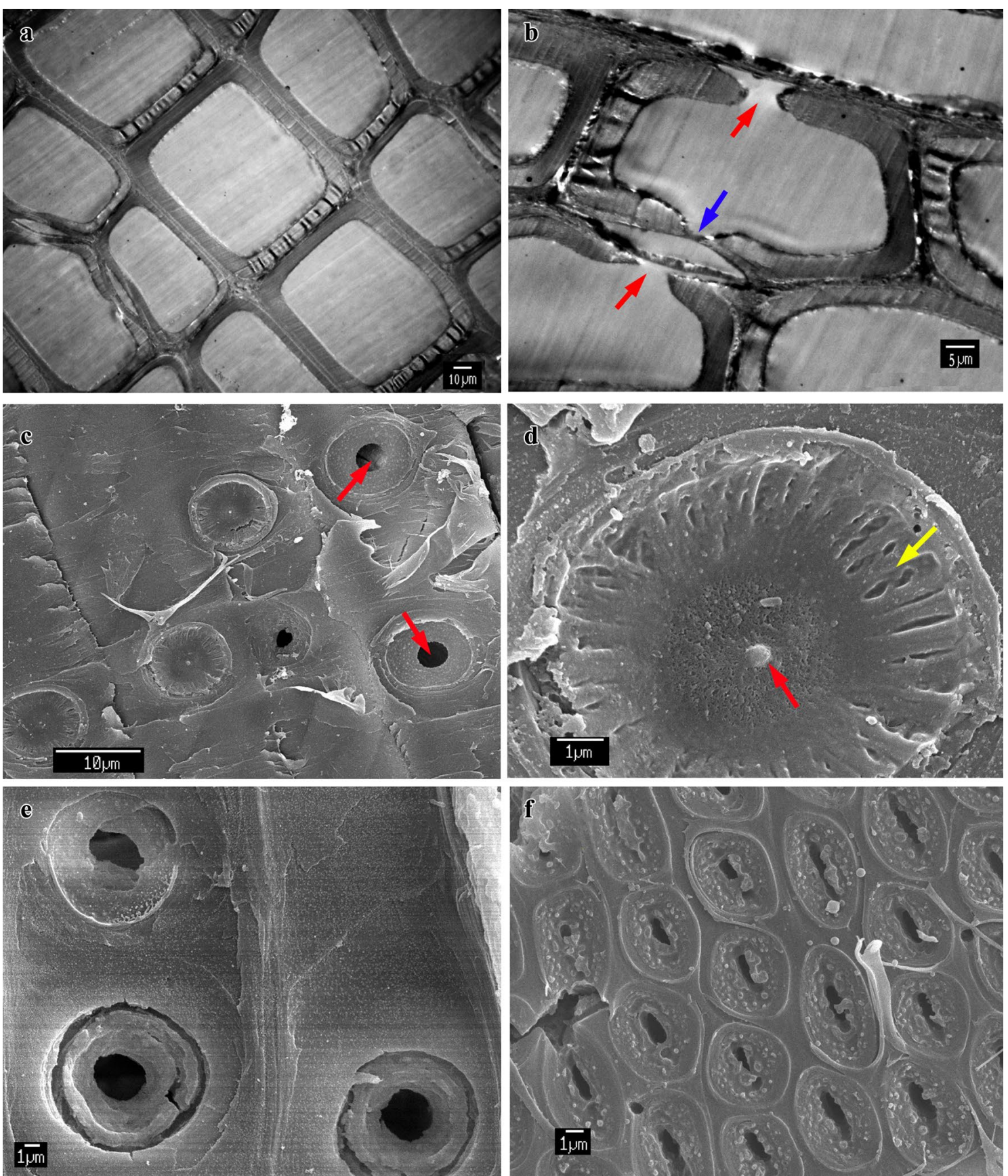

Fig. 3 The absent erosion cell structures of archaeological woods from Nanhai No. 1 shipwreck. a Complete cell layer, cell wall remain intact and the very close connections between the cells (Sample 8, TEM). b The bordered pits (red arrows) and pit membrane (blue arrow) under higher magnification (Sample 8, TEM). c A bordered pit (red arrow) in a tracheid on the longitudinal section (Sample 20, SEM). d A bordered pit under high magnification, showed the pit membrane (yellow arrow) and the pit plug (red arrow) clearly (Sample 20, SEM). e The cross field pits on the tracheid (Sample 15, SEM). f Vessel pits from Sample 17 (SEM)

(SB). For serious erosion samples, with serious damage inside of the cell, and some cell pits filled with a large number of bacteria, such as tracheids (Fig. 6c), all cell types could still be identified. Overall, the arrangement of the whole plant cell layer was still orderly (Fig. 6d). It shows that the bond role of middle lamella should not be underestimated.

When more serious erosion happened, the cell layer was dilapidated. The cell types could not be distinguished easily. The only visible ray cell layer was no 

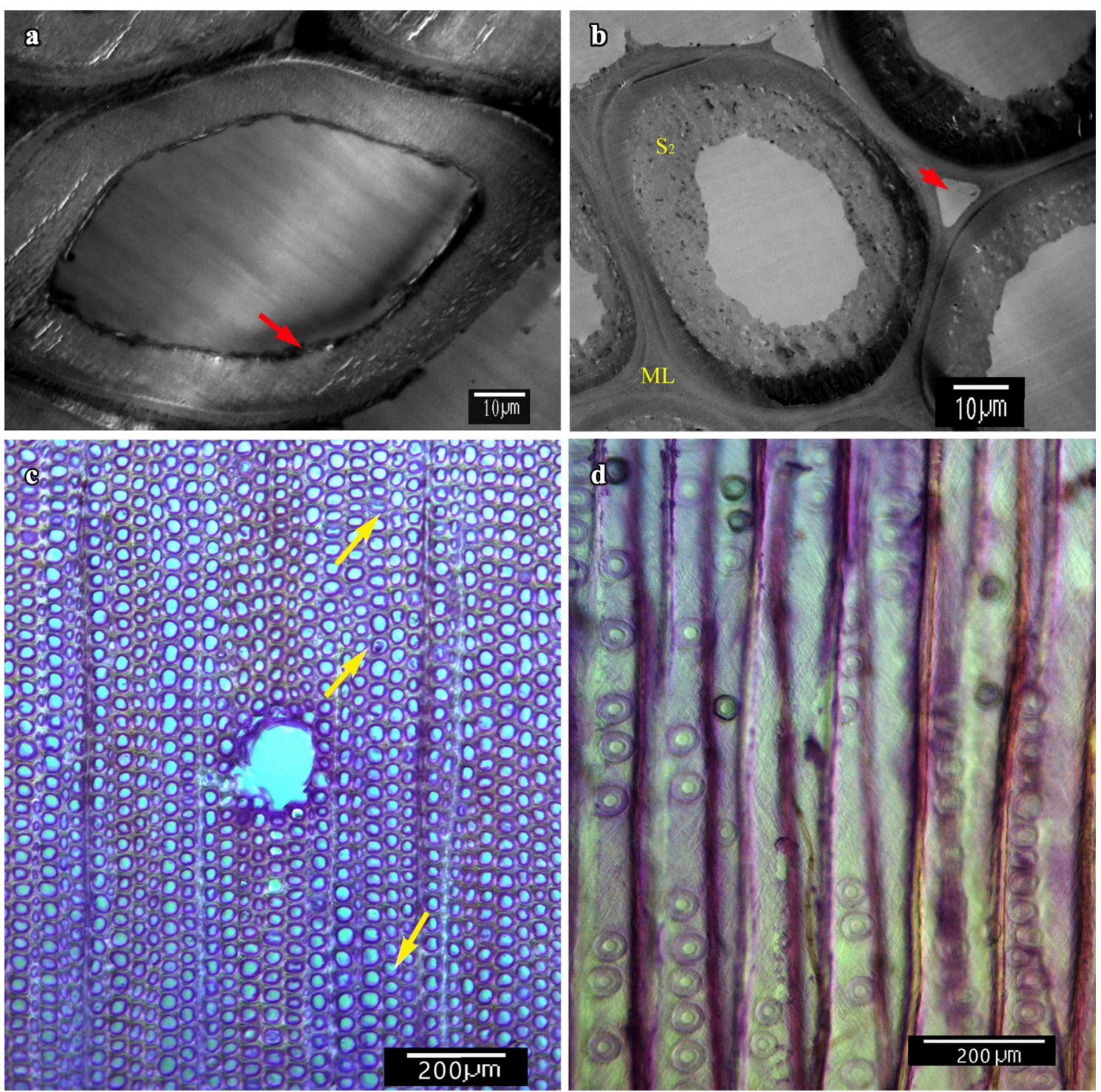

Fig. 4 The weak erosion cell structures of archaeological woods from Nanhai No. 1 shipwreck. a A cell with slight injury (red arrow) of the connection between the cell wall and the cell cavity (Sample 2, TEM). b Another ellipse cell from Sample 3 which presented a thicker $S_{2}$ layer and no $\mathrm{S}_{3}$ layer (TEM). c Ray cells are intact (arrows) in Sample 5 (LM). d A slight corrosion in ray cells from longitudinal section of Sample 7 (LM)

longer complete. Some of them disappeared when the cell layer distorted, and some only had the entire contour of the ray cell layer left (Fig. 7a). With thinning of the middle lamella (Fig. 7b), the cell frame could not be supported, and fractured under the constant erosion of bacteria (Fig. 7c). The whole cell layer was distorted and abstracted with outflow of the cellular residue (Fig. 7d).

\section{Discussions}

Timber species of Nanhai No. 1 shipwreck

According to the analysis on the timber species, the wood components in the Nanhai No. 1 sunken ship were mostly Pinus massoniana, Terminalia hainanensis and Fokienia hodginsii. Other types of timber species had a lower proportion. Because of the natural characteristics, P. massoniana, T. hainanensis and $F$. hodginsii had been used to build ships for a long time in China [23, 28]. It was found that the timbers shown in this study were the main materials of other ancient Chinese sunken ships, which were wooden ships and excavated along the Chinese coast [33-36].

In contrast, it had been proven by ancient sunken ships that all species of pines, fir and cypresses were used as the main materials to build ancient ships in 

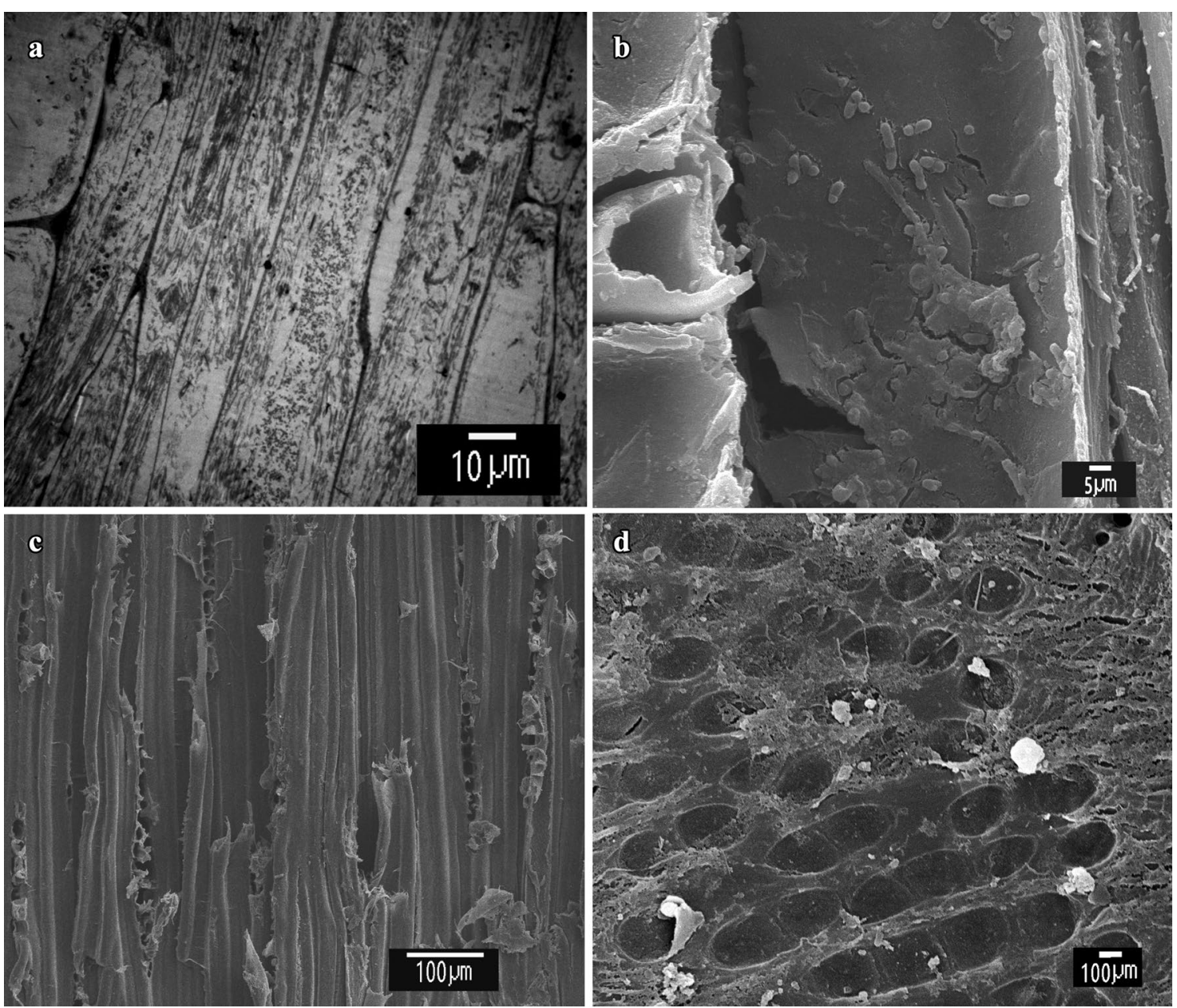

Fig. 5 The moderate erosion cell structures of archaeological woods from Nanhai No. 1 shipwreck. a A lot of black erosion residue in the eroded fibroblast cell cavities (Sample 9, longitudinal section of thin section, TEM). b Bacteria eroding tracheids (Sample 16, SEM). c Soft duct cells from Sample 6 (SEM). d Ray cells vulnerable and loose connections between the tracheid cells (Sample 4 SEM)

other countries, especially in Europe. It might be due to the smaller sizes of these wooden ships as compared to Chinese ancient wooden ships. Some species of medium and small arbor trees could be used to build the ship components. For example, in several ancient wooden ships (with the length of 4-14 m) found in Pisa, Italy, 18 wood species were identified. Besides pines, fir and cypresses, Fraxinus excelsior, Juglans regia, Ulmus cf. minor, Quercus sp., Alnus cf. glutinosa, Fagus sp., Ficus carica, Olea europaea, Populus alba, Cornus sp. and Salix sp. were used as materials for ship building as well [37, 38]. Similar cases were also reported on another 3 ancient sunken ships from Naples, Italy [39]. Another case appeared on a sunk flat-bottomed barge of the Roman Empire period (AD 3rd Century) which was found in the Ljubljanica River of Slovenia, the major components of the barge were made from beech wood (Fagus sylvatica) [40].

\section{The bacterial erosion degree of the wooden samples} from Nanhai No. 1 shipwreck

According to Klaassen [31], different timber species presented different erosion degrees. For example, the samples from Pinus massoniana were basically in a minor erosion level, and the samples from Terminalia hainanensis had moderate to heavy erosion. A similar result was also observed in a previous study on shipwrecks [41].

Although Klaassen's assessment system for bacterial erosion on the woods was mainly derived from spruce, pine, oak, alder and fir, the basic principle was evaluation of the erosion degree to the xylem cells of the trees. Thus, this assessment system is an important reference for this study. A few studies showed that the process of wood bacteria erosion could be affected by many factors [42-46]. Therefore, the physiological and biochemical reactions in the process of bacterial erosion of wood need to be further studied. 


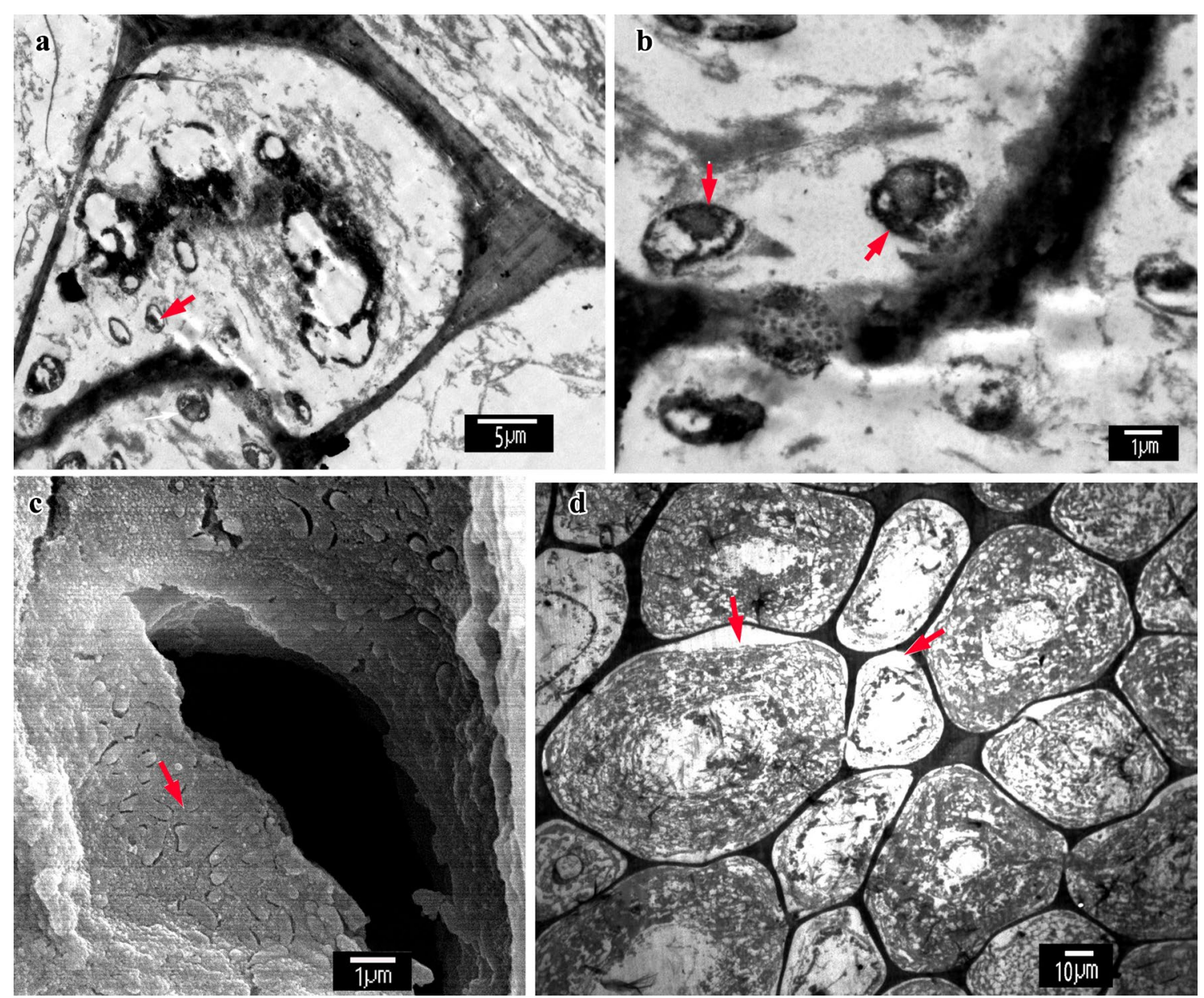

Fig. 6 The severe erosion cell structures of archaeological woods from Nanhai No. 1 shipwreck. a Active secondary bacterial degraders (arrow) in cells (Sample 10, TEM). b Bacteria (arrow) decomposed the black erosion residue into granular (Sample 10, TEM). c The pits of tracheid encroached by a large number of bacteria (arrow) (Sample 10, SEM). $\mathbf{d}$ Cells only supported by the middle lamella but still in neat arrangement, secondary cell wall has been separated from the medium lamella (arrow) (Sample 17, TEM)

\section{The interior changes of the shipwreck wooden components}

By the observations and comparisons on the 20 wooden samples from Nanhai No. 1 shipwreck, with EM and LM, it was found that well-preserved samples (hard wood) had no traces of microbial internal erosion, with intact and tightly connected cells. However, those soft wood samples eroded by bacteria, EB and TB. The results showed, that in all severe erosion wooden samples, almost all cells were eroded by bacteria, with only the medium lamella framework in the entire cell wall left, or the $S_{3}$ layer retained. The cell cavity was filled with the erosion residue, composed of bacterial mucus, bacterial fragments, and lignin of the cell wall (Fig. 6). Although not all of the erosion characteristics were clearly identified, it can be speculated that there was no fungus erosion based on the observation of the integrity of the middle lamella, the distribution of the erosion residue and the location of the shipwreck site. In many cell cavities, black and ordered stripes were visible on the stack tunnels, which is a typical feature of TB erosion [47].

In addition, the presence of bacterial erosion activity was observed in some cells, exhibiting different distribution patterns and activity characteristics from that of $\mathrm{EB}$ and $\mathrm{TB}$, with no erosive cell composition, but only black erosive residue left around the bacteria. When bacteria erosion of pine was observed, Björdal et al. [48] found that the eroded residue density, near to the middle lamella, was lower than that in the cell cavity. They suggested that it was an indication of secondary bacterial degraders which feed on the eroded residue. This bacterium had no degradation capability on the normal plant cellular components, and the site (place or room) where they stayed could be clear. They could be called "cleaning bacteria". 

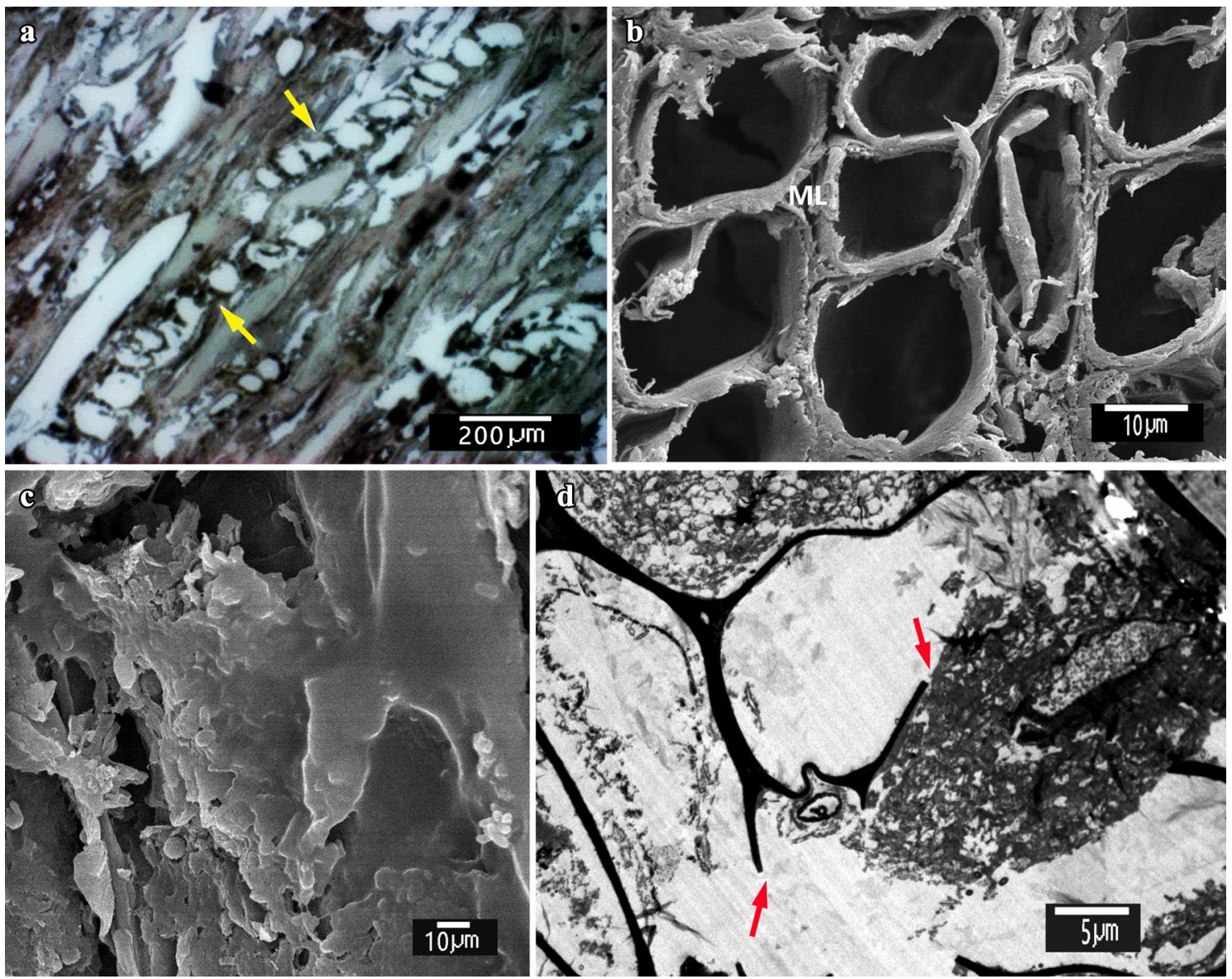

Fig. 7 The total erosion cell structures of archaeological woods from Nanhai No. 1 shipwreck. a The cell layer blurred and only partial middle lamella of the ray cells (arrow) left (Sample 19, tangential section, LM). b Fragile middle lamella frame from Sample 11 (SEM). c Deformed cell and the cell cavity filled with bacteria (Sample 18, SEM). d Cells deformation, cell walls ruptured (arrow) and residues outflow from cells (Sample 11, TEM)

In general, the wood samples of the Nanhai No. 1 shipwreck showed absent to severe erosion by bacteria in cell structures. As compared to the hull of Xiaobaijiao No. 1 shipwreck, the wood erosion of a wooden merchant ship, sunk about 200 years ago (Qing Dynasty) in Zhejiang, was more serious [41]. Another case was from Nan'ao No. 1 shipwreck, a wooden ship sunk east of Guangdong about 600 years ago (Ming Dynasty) [19]. With EM observations, it was found that most of the wood samples were seriously corroded. The third case was from Huaguangjiao No. 1, a Song Dyansty Chinese ancient shipwreck found in Huaguangjiao Island, in the south middle of the Xi'sha Islands 1996 [49]. Shen et al. [50] found that 5 wood samples from this shipwreck were degraded between serious and total erosions. Based on the information from archaeological excavations of the Xiaobaijiao No. 1 shipwreck, a part of the ships keel and floor plates were exposed to the seabed surface, and other parts of the ship were covered by about $0-60 \mathrm{~cm}$ thick of cracked oyster shell and sandy sediment [11]. The Nan'ao No. 1 shipwreck sunk site was in the reefs, although the wreck was surrounded by soft sand, the hull was exposed to the sea water for a long time, and the water current there was also faster [13]. The original location of the Nanhai No. 1 sunken ship was in the silt bottom circumstance location, $24 \mathrm{~m}$ below the sea surface, and the whole surface of the shipwreck was covered by about $2 \mathrm{~m}$ thick silt. By the underwater exploration, it was confirmed that the ship's hull was well preserved, and the ship structure under the upper and lower decks was basically complete [20]. By comparing the sunken site circumstances of different shipwrecks, it can be found that, after sinking, the former ships (Xiaobaijiao No. 1 and Nan'ao No. 1 shipwrecks) were located at the high $\mathrm{O}_{2}$ content circumstances with water flowing quickly and water exchanging frequently, facilitating the survival and reproduction of aerobic bacteria and boring animals. 
On the contrary, the Nanhai No. 1 shipwreck was sunken down to a place where the seabed was relatively flat, water flowed slowly, and more suspended particles were settled. The hull of Nanhai No. 1 shipwreck was almost covered completely by a thick silt layer. The silt layer had played an objective role in isolating the wreck itself from the seawater. Between marine sediments and water, material exchanges always happen [51], while the exchanges mainly occur in the place between the water and shallow surface of the sediments [52-56]. Thus, after the sinking of the ship, material exchange between the sediment deposited on the ship and the overlying water happened.

The sediment pore water could also play a role in the hull degradation. With the thickening of the sediments, the material exchange between the sedimentwater interface in the deep sediments were weaker and weaker. It formed a relatively stable environment for deep sediment pore water, and the influence of the sea water changes on the ship hull was relatively small as well. At the macroscopic level, the hull timber of the Nanhai No. 1 was preserved much better than that of Xiaobaijiao No. 1, and Nan'ao No. 1. At the micro level, the number of bacteria detected in the Nanhai No. 1 wood was much less than that of Xiaobaijiao No. 1 [57]. The silt-covered anaerobic environment was actually protecting the ancient sunken ships, of which was also found in European countries [38]. The cultural relics protection departments in some European countries follow the silt-covered principle to protect the wreck site and the original site of the ancient sunk ship [58].

\section{Conclusions}

The study on the microscopic and submicroscopic structures of 20 wooden components from an ancient shipwreck (Song Dynasty, 800 years ago) in the South China Sea, Nanhai No. 1, discovered:

- The wooden components were from 6 timber species, including Pinus Massoniana, Fokienia Hodginsii, Terminalia Hainanensis, Mischocarpus Oppositifolius, Alnus Trabeculosa, and Mussaendopsis Beccariana.

- Wooden components mainly came from the large trees, related to the longer history and size of bigger Chinese ship-buildings.

- Referring to Klaassen's assessment system for bacterial erosion on the wood, most of the wood components showed weak to moderate erosion.

- Different timber species presented different erosion degrees. P. massoniana were basically in a minor erosion level, and the samples from T. hainanensis were moderate to heavy erosion.
- The erosive microbes of the sunken ship were mainly erosion bacteria (EB) and tunnelling bacteria (TB).

- Although the sunken time is longer, the wood structure of the Nanhai No. 1 sunken ship is the best preserved among all shipwrecks in southeast China.

The marine environment of the wreck site, including the sediments covered on the surface of the wreck, played a very important role in protecting wooden parts of the ship wreck.

\section{Authors' contributions}

MG, QZ and RX contributed to sample and data analysis, interpretation and manuscript writing. XF was involved in the sample analysis. DC was involved in the sample preparation. JS and YC were involved in sampling. All authors read and approved the final manuscript.

\section{Author details}

${ }^{1}$ School of Life Sciences, Sun Yat-sen University, Guangzhou 510275, China. ${ }^{2}$ Chinese Academy of Forestry, Beijing 100091, China. ${ }^{3}$ Dongguan Botanical Garden, Dongguan 523086, China. ${ }^{4}$ Underwater Cultural Heritage Protection Center, State Administration of Cultural Heritage, Beijing 100192, China. ${ }^{5}$ The Cultural Relics Protection and Archaeology Institute of Guangdong, Guangzhou 510075 , China.

\section{Acknowledgements}

The authors are very grateful to Mrs. James Magee and Paul Clarke from UK, and Dr. Zhang S. P. from USA for their helps in English of the manuscript.

\section{Competing interests}

The authors declare that they have no competing interests.

\section{Availability of data and materials}

Not applicable.

\section{Ethics approval and consent to participate}

The paper presented is the work made by our independent research. All data cited in the paper were from publicly available datasets and published literatures. In addition to the content of particular references, this paper does not contain any work that has been published or written by any other individual or group. Individuals, who have made important contributions to the study of this paper, have been clearly demonstrated in the acknowledgements.

\section{Funding}

This research was supported by the funding of the Chinese State Administration of Cultural Relics. Award Number: 413174400001. Grant Recipient: Jian Sun.

\section{Publisher's Note}

Springer Nature remains neutral with regard to jurisdictional claims in published maps and institutional affiliations.

Received: 20 April 2018 Accepted: 6 September 2018

Published online: 10 September 2018

\section{References}

1. Xu RL. Research on bacteria causing damage in water-saturated archaeological wood and their identification. Sci Conserv Archaeol. 2013;25(3):104-10 (in Chinese).

2. Rowell RM, Barbour RJ. Archaeological wood: properties, chemistry, and preservation. Washington: American Chemical Society; 1990.

3. Kim YS, Singh AP, Nilsson T. Bacteria as important degraders in waterlogged archaeological wood. Holzforschung. 1996;50:389-92. 
4. Blanchette RA. A review of microbial deterioration found in archaeological wood from different environments. Int Biodeterior Biodegrad. 2000;46:189-204.

5. Björdal CG, Nilsson T, Daniel GE. Microbial decay of waterlogged archaeological wood found in Sweden: applicable to archaeology and conservation. Int Biodeterior Biodegrad. 1999;43:63-71.

6. Klaassen WMRK. Speed of bacterial decay in waterlogged wood in soil and open water. Int Biodeterior Biodegrad. 2014;86:129-35.

7. Daniel G, Nilsson T. Ultrastructural observations on wood degrading erosion bacteria. Int Res Group Wood Preserv. 1986;1283(5):26-30.

8. Landy ET, Mitchell JI, Hotchkiss S. Bacterial diversity associated with archaeological waterlogged wood: ribosomal RNA clone libraries and denaturing gradient gel electrophoresis (DGGE). Int Biodeterior Biodegrad. 2008;61:106-16

9. Singh AP. A review of microbial decay types found in wooden objects of cultural heritage recovered from buried and waterlogged environments. J Cult Herit. 2012;13S:16-20.

10. Quanzhou Museum of Overseas Traffic History. The Excavation and Research of the Sea Ships in the Song Dynasty of the Quanzhou Bay. Beijing: Ocean Press; 1987 (in Chinese)

11. Lin GC, Wang GY, Jin T. A brief excavation report in 2012 on the sunken ship in Qing Dynasty in Xiangshan County, Zhejiang. Archaeology. 2015;6:54-67 (in Chinese)

12. Bao CL. Underwater archaeology of the of Huaguangjiao No. 1 shipwreck in the South China Sea. J South Chin Sea Stud. 2015;3:55-9 (in Chinese).

13. Cui Y. The Ming Dynasty sunk ship of Nanao No. 1 in Shantou, Guangdong. Archaeology. 2011;7:39-46 (in Chinese).

14. Li GQ. Study on shrinkage of waterlogged ancient wood. Preserv Cult Relics. 1987:4:70-9 (in Chinese).

15. Zhang JP, Chen N. Studies of the wood property of the waterlogged Paulownia unearthed from the Han Dynasty tomb of Sishui Kingdom. Sci Conserv Archaeol. 2005;17(4):15-22 (in Chinese).

16. Zhang JP, Zhang R. The index on the degradation of acrhaoeloglcal wood. Sci Conserv Archaeol. 2007;19(2):34-7 (in Chinese).

17. Zhao HY, Wang JW, Cui GS. The physicochemical properties and microstructure characterization of waterlogged wood relics. Southeast Cult. 2008;204:89-92 (in Chinese)

18. Zhao HY, Wang XX, Gao JH, et al. Micromorphological structure and physical properties of unearthed catalpa wood. J Beijing Fores Univ. 2008;30(5):134-8 (in Chinese).

19. Wang YL. Study on deterioration of waterlogged archaeological wood salvaged from Nanao No. 1 shipwreck by scanning electron microscopy (SEM). J Centr South Univ Fores Technol. 2013;33(6):48-54 (in Chinese).

20. Liu ZY. Archaeological excavation of Nanhai No. 1 Shipwreck. Beijng: Science Press; 2011 (in Chinese)

21. Wu JC, Zhang YQ. The overall salvage of the Nanhai No. 1" ancient sunken ship. Navig Chin. 2008;31(4):383-7 (in Chinese).

22. Sun J, Liu CJ. The Archaeological Report of the Nanhai No. 1 Sunken Ship, Il: excavations from 2014 to 2105. Beijing: Cultural Relics Publishing House; 2017 (in Chinese)

23. Cheng JQ, Yang JJ, Liu P. Chinese Wood chorography. Beijing: China Forestry Press; 1992 (in Chinese).

24. He TX. Wood anatomy. Guangzhou: Sun Yat-sen University Press; 1994 (in Chinese)

25. Spurr AR. A low viscosity epoxy resin embedding medium for electron microscopy. J Ultrastr Res. 1969;26(1):31-43.

26. Reynolds ES. The use of lead citrate at high $\mathrm{pH}$ as an electron opaque stain in electron microscopy. J Cell Biol. 1963;17:208-12.

27. Singh AP, Nilsson T, Daniel GF. Ultrastructure of the attack of the wood of two high lignin tropical hardwood species. J Inst Wood Sci. 1987;11:26-42.

28. Jiang XM, Chen YM, Yin YF. Gymnosperms Wood of China. Beijing: Science Press; 2010 (in Chinese).

29. Editorial Committee of China Flora China Flora. Beijing: Science Press; 2004-2013 (in Chinese).

30. Richter HG, Dallwitz MJ. Onwards. Commercial timbers: descriptions, illustrations, identification, and information retrieval; 2016. http://delta -intkey.com/wood/index.htm. Accessed 14 Dec 2017.
31. Inside Wood Onwards. http.//insidewood lib ncsuedu/2004 Accessed 10 July 2017.

32. Klaassen WMRK. Bacterial decay in wooden foundation piles-Patterns and causes: a study of historical pile foundations in the Netherlands. Int Biodeterior Biodegrad. 2008:61(1):45-60.

33. Chen ZR. Wood identification of Song sea ship at Quanzhnu Bay. The Excavation and Research of the Sea Ships in the Song Dynasty of the Quanzhou Bay. Beijing: Ocean Press; 1987. p. 147-50 (in Chinese)

34. Xu YJ, Wu DP, Li DG. Wood identification of an ancient boat as made in Yuan Dynasty and unearthed in Nantong, China. J Fujian Coll Fores. 1995;15:87-90 (in Chinese)

35. Jin T, Lin GC, Wang GY. Identification of tree species and of timbers on the Qing Dynasty Xiaobaijiao No. 1 shipwreck found in Xiangshan, Ningbo, Zhejiang. Sci Conserv Archaeol. 2015;27(2):34-9 (in Chinese)

36. Feng XX, Gao MG, Jin T, et al. Supplementary identification of wood species from the Qing Dynasty shipwreck Xiaobaijiao No. 1 in Ningbo. Sci Conserv Archaeol. 2017;29(1):72-7 (in Chinese)

37. Giachi G, Lazzeri S, Lippi MM, et al. The wood of "C" and "F" Roman ships found in the ancient harbour of Pisa (Tuscany, Italy): the utili-sation of different timbers and the probable geographical area which supplied them. J Cult Herit. 2003;4:269-83.

38. Giachi G, Capretti C, Lazzeri S, et al. Identification of wood from Roman ships found in the docking site of Pisa (Italy). J Cult Herit. 2017;23:176-84.

39. Capretti C, Macchioni N, Pizzo B, et al. Characterization of the waterlogged archaeological wood: the three ships found in Naples (Italy). Archaeometry. 2008;50:855-76.

40. Cufar K, Merela M, Erič M. A Roman barge in the Ljubljanica River (Slovenia): wood identification, dendrochronological dating and wood preservation research. J Archaeol Sci. 2014:44:128-35.

41. Gao MG, Zhang QF, Jin T, et al. Observation and damage assessment of microbial diseases in some wooden cultural relics from the ancient marine shipwreck, Ningbo Xiaobaijiao No. 1. Sci Conserv Archaeol. 2017:29(6):93-102 (in Chinese).

42. De Jong J. Conservation techniques of old waterlogged wood from shipwrecks found in the Netherlands. In: Walters AH, editor. Biodeterioration Investigation Techniques. London: Applied Science Publishers; 1977. p. 295-338.

43. Grattan DW, Clarke RW. Conservation of waterlogged wood. In: Pearson C, editor. Conservation of marine archaeological objects. London: Butterworth; 1987. p. 164-206.

44. Hedges IJ. The chemistry of archaeological wood. In: Rowell RM, Barbour RJ, editors. Archaeological Wood. Properties, Chemistry and Preservation. Washington DC: American Chemical Society; 1990. p. 111-40.

45. Sakai H. Process of deterioration of buried wood. Mokuzai Gakkaishi. 1991;37:363-9.

46. Björdal CG. Microbial degradation of waterlogged archaeological wood. J Cult Herit. 2012;13:118-22.

47. Singh AP, Butcher JA. Bacterial degradation of wood cell walls: a review of degradation patterns. J Inst Wood Sci. 1991;12(3):143-57.

48. Björdal CG, Daniel G, Nilsson T. Depth of burial, an important factor in controlling bacterial decay of waterlogged archaeological poles. Int Biodeterior Biodegrad. 2000;45:15-26.

49. The Underwater Archaeological Research Center of Chinese National Museum, the Cultural Relics Protection and Management Office of Hainan. Underwater Archaeology in Xisha Islands. Beijing: Science Press; 2006 (in Chinese)

50. Shen DW, Li NS, Fu Y, et al. Study on wood preservation state of Chinese ancient shipwreck Huaguangjiao 1. J Cult Herit. 2018;32:53-9.

51. Song JM. Sea water interface chemistry in Chinese offshore sediments. Beijing: Ocean Press; 1997 (in Chinese).

52. Li D. Impacts of bioturbation on distribution of dissolved oxygen at sediment-water interface. Master Thesis of Ocean Univ China. 2013 (in Chinese)

53. Wang GQ Zhang S, Li DP, et al. Effects of environmental factors on ammonia nitrogen adsorption and desorption in the surface sediments of Haizhou Bay. Ecol Environ Sci. 2017:26:95-103 (in Chinese).

54. Mackin JE, Aller RC. Ammonium adsorption in marine sediment. Limnol Oceanogr. 1984;29:250-7.

55. Song JM, Li PC. Studies on characteristics of nutrient diffusion fluxes across sediment water interface in the district of Nansha Islands, South China Sea. Mar Sci. 1996;5:43-50 (in Chinese) 
56. Ni ZX, Zhang L, Yu S, et al. The porewater nutrient and heavy metal characteristics in sediment cores and their benthic fluxes in Daya Bay, South China. Mar Pollut Bull. 2017;124:547-54.

57. Li QX, Cao LX, Tan HM, et al. Analysis of the bacterial communities in the waterlogged wooden cultural relics from the Nanhai No. 1 shipwreck. Acta Microbiol Sin. 2018;58:1439-52 (in Chinese).
58. Bergstrand T. The Danish 17th-century man-of-war stora Sofia: documentation and in situ preservation. Int J Nauti Archaeol. 2010;39:56-65.

\section{Submit your manuscript to a SpringerOpen ${ }^{\odot}$ journal and benefit from:}

- Convenient online submission

- Rigorous peer review

- Open access: articles freely available online

- High visibility within the field

- Retaining the copyright to your article

Submit your next manuscript at $\boldsymbol{\nabla}$ springeropen.com 